DOI 10.18551/rjoas.2021-08.12

\title{
UTILIZATION OF ANIMAL MANURE (COW DUNG) AND AGRICULTURAL WASTE (HUSK ASH) AS ALTERNATIVE BUILDING MATERIALS IN SADE VILLAGE, INDONESIA
}

\author{
Wirjaatmadja Ruswandono* \\ Faculty of Veterinary Medicine, University of Wijaya Kusuma Surabaya, Surabaya, Indonesia \\ Paing Johan \\ Department of Civil Engineering, Faculty of Technique, University of Wijaya Kusuma \\ Surabaya, Surabaya, Indonesia \\ *E-mail: atmajaros@uwks.ac.id
}

\begin{abstract}
This research was conducted to determine the potential use of organic waste as a green building material, especially animal waste (cow dung) and agricultural waste (husk ash). This research is motivated by incidents in the community that use this waste as a substitute for plastering on their houses made of bamboo and previous research using husk ash as bricks. The research composition for each sample used $75 \%$ animal waste and $25 \%$ husk ash, with the variable being sought was the moisture content required. Animal waste in the form of cow dung that is used comes from farms around the community's residence, and agricultural waste in the form of husk ash from rice mills located around residential areas. As a comparison, we used sand cement mortar with a ratio of 1:5. The results showed that the use of $0.6 \mathrm{~L} / \mathrm{kg}$ of water obtained an average compressive strength of 28 days of age, namely $4.2 \mathrm{~kg} / \mathrm{cm}^{2}$. In the test specimen using $0.4 \mathrm{~L} / \mathrm{kg}$ water with the same composition, it turned out that the paste was difficult to stir or was too thick. Whereas those using $0.8 \mathrm{~L} / \mathrm{kg}$ and $1 \mathrm{~L} / \mathrm{kg}$ water obtained the mixture was too soft, the drying process was too long.
\end{abstract}

\section{KEY WORDS}

Animal waste, agricultural waste, green building material.

Traditional settlements hold traditional and cultural values related to local community beliefs (Leonard al 2013). Currently, there is a decrease in people who still have local wisdom in an area. Local wisdom is the principles and methods understood, obeyed, and applied by local communities, with their environment being transformed into traditional values and norms (Dewi \& Putri 2019). One of Indonesia's traditional settlements is in Sade Hamlet, Rembitan Village, Central Lombok, NTB. This hamlet is known to maintain the customs of the Sasak tribe still. This tribe is native to the island of Lombok, which has a cultural system in the book Negarakertagama written by Empu Nala from Majapahit. The existence of traditions that exist until now shows that the Sasak tribe can preserve its traditions (Ahyar \& Abdullah 2019). One of the ways they maintain their habits is through mixed marriages.

The house has a function as a shelter. Besides, it is a home for residents of the past who have aesthetic and philosophical values. For the Sasak people, the house is in the sacred (profane) and profane dimensions simultaneously (Wirawan \& Widana 2020), so that the Sasak traditional house has a function as a shelter and is also used as a place for religious rituals as a manifestation of belief in God's ancestral spirit (Waterson 2012) (papuk baluk, bale), etc. The physical value of the Sade Hamlet community's physical form is the use of natural materials applied to the house's envelope. This material starts from the roof using coconut fiber, the walls using woven bamboo, and the floor using the ground. Apart from having an aesthetic value in the building, this building also has a philosophical significance in the outer and inner spaces (Scruton 2013). In outer space, the application of intellectual values in the form of the orientation of structures that may not face the mountain is respect for ancestral spirits. 
The formation of traditional settlements is influenced by several factors, which can be seen from ecological elements (Gilbert 2012). These elements include physical characteristics, humans, society, shells, networks. In this research, the aim is to explore local wisdom in the Sade Hamlet community, which is observed in macro and micro settlements.

\section{MATERIALS AND METHODS OF RESEARCH}

The first step of this research is to explore and study the Sade Village community's local wisdom. It is to determine the extent of the cultural richness of the Sade people holistically. The second step is to examine the mortar material used as wall and floor coatings using cow dung waste. The material used in this study is organic waste consisting of animal waste (cow dung) and agricultural waste (husk ash). The percentage of materials used as test objects is $75 \%$ animal waste and $25 \%$ agricultural waste. The comparative data is obtained from each resident's survey results who use the material. Determination of water use in this study is based on usage in the community, namely $0.6 \mathrm{~L}$ per $1 \mathrm{~kg}$ of animal waste mixed with $0.250 \mathrm{~kg}$ of husk ash. But here also uses a water ratio of $0.4 \mathrm{~L}, 0.8 \mathrm{~L}$, and $1 \mathrm{~L}$ as a comparison of the sample to get maximum results. The analysis of material and water requirements for one specimen is in table 3.

The test object's treatment is intended to protect the test object from evaporation or excessive water addition before being tested. At this stage, the test object is protected from rain and sunlight by placing the test object in a protected place. Meanwhile, the hardened specimens' treatment is carried out by aerating the specimens until the specified time limit, namely: 7,14 and 28 days without immersing.

\section{RESULTS AND DISCUSSION}

Sade is one of the hamlets in Rembitan village, Pujut, Central Lombok. This hamlet is known to maintain the customs of the Sasak tribe. The research object's location is in the hills with an altitude of 120-126 masl with 5,500 m2. Based on Schmid and Ferguson's classification, Central Lombok Regency has a climate D and climate E, which is tropical rain with a dry season, namely from November to May, while rainfall ranges from 1,000 to 2,500 $\mathrm{mm}$ a year. Sade Hamlet has 150 houses with 700 residents. Geographically, Sade Hamlet is located at 850 South Latitude and 116 East Longitude with the following boundaries, West (Dusun Penyalu), East (Dusun Lentak), North (Dusun Selak), and South (Dusun Selemang).

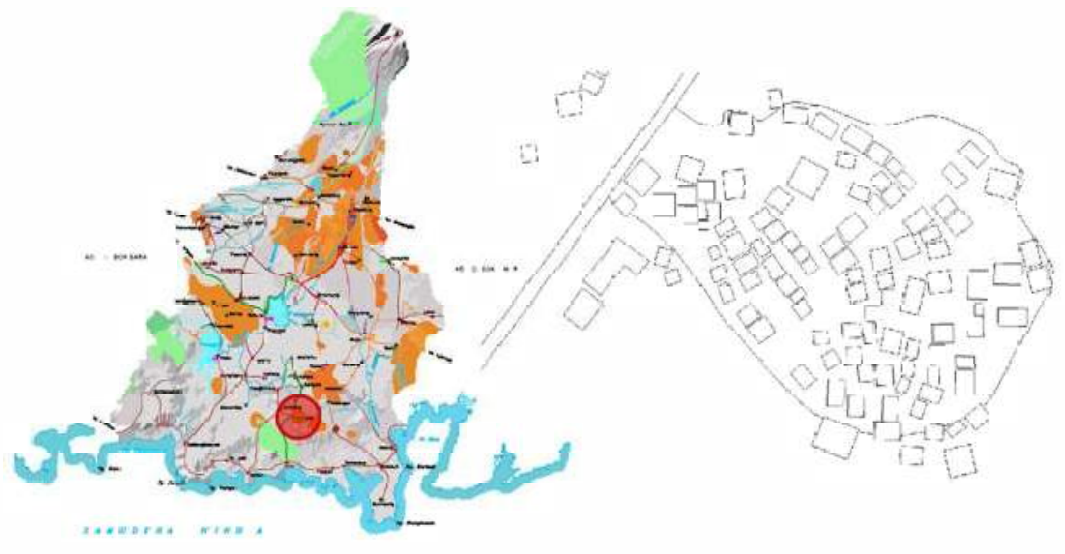

Figure 1 - The object of study: Sade Village, Central Lombok

The Sasak people formed Sade Hamlet. According to interviews, it appeared in 1907. In 1975 this hamlet was initiated into a historical tourism village. Historical Tourism Village Sade Hamlet is a rural area that offers an overall atmosphere that reflects the countryside's authenticity. Whether from socio-economic life, socio-culture, customs, daily life, having a 
typical village architecture and spatial structure, or unique and exciting economic activities, it can develop various tourism components.

As a traditional Sasak tribe hamlet, Sade Hamlet still adheres to the ancestors' traditional values amidst the increasingly dominating modernization. The Dusun Sade community is led by Jeru Keliang, who was appointed based on community consultation (Widisono 2019). The community entrusts leaders to preserve the village and uphold traditional ancestral values. In addition to this, the village head has village officials to assist them and village officials who assist in village administration.

Table 1 - Sade village community leader

\begin{tabular}{|c|c|}
\hline No. Jobs & Job Descriptions \\
\hline 1. Jeru Keliang & $\begin{array}{l}\text { The prominent leaders of indigenous tribes that cover all aspects of customary } \\
\text { religious and irrigation }\end{array}$ \\
\hline 2. Jeru Warah & Deputy village head who runs village duties if the village head is absent \\
\hline 3. Pengelingsir & Village elders \\
\hline 4. Inen Pemole & Leaders in the religious field \\
\hline 5. Mangku Belian & Leaders in the religious field \\
\hline
\end{tabular}

Dusun Sade, as a traditional village, still applies their traditional values (Hamzah \& Irfan 2018). The orientation of the house facing east-west. The building's direction to the east-west is considered a blessing, whereas if it faces north, where it meets Mount Rinjani. It is deemed to be taboo because of the residence of Dewa Gunung Rinjani.

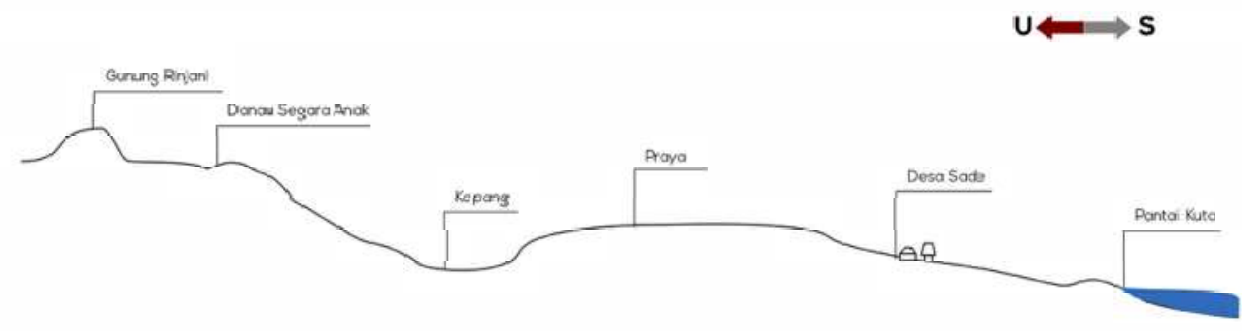

Figure 2 - The building orientation towards Mount Rinjani

Local people's beliefs influence the choice of hilly locations (Diaz et al 2015). Residential locations were chosen higher than other locations for the following reasons. First, cosmic belief in supernatural powers exists in the local community's upper realm as a blessing and misery. Second, security for the community, the top of the hill, is a strategic place for local people to organize defence due to conflicts with other hamlets. Third, Hilly areas are infertile areas; therefore, the community uses the surrounding agricultural land with less land. Settlement patterns in traditional societies have different characteristics. It is based on the essence in people's thinking because it expresses community identity's fundamental values. The settlement pattern in Sade Hamlet has a linear pattern (Widisono 2019). The formation of this pattern is because the community has a livelihood as farmers. The fertile land around the house made the house follow the cultivated land around it.

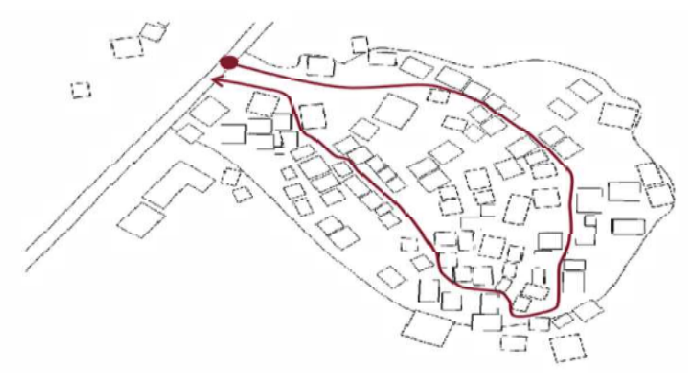

Figure 3 - Settlement pattern 
In the site plan, the settlement arrangements in Sade Hamlet are close together. The kinship in the hamlet also causes this arrangement. At Sade Hamlet, one way to preserve their culture is to marry their own family (Kusumowidagdo et al 2019). This method also influences settlement patterns that are close to each other.

Merariq for the Sasak community means maintaining self-respect and portrays a Sasak man's masculinity because he has succeeded in taking (running away) a girl's idol (Erwinsya et al 2020). Marariq is a process in marriage. In this process, the man kidnaps a woman who will be his future wife for three days and three nights at his aunt or uncle's house. After being kidnapped for three days and three nights, the two were reunited with their parents to meet with neutral parties to propose to the girl.

Weaving activities are activities that women mostly carry out (Widisono 2019). Weaving is the second source of income after planting. Women must be able to weave songket before marriage. Songket woven cloth is used for wedding dowries. They must provide 15 pieces of songket cloth, meaning that a woman must incorporate a songket show if a wife can support income. Because men only have one livelihood as a farmer, if the weather is terrible or not during the rice season, women make and sell cloth for economic income.

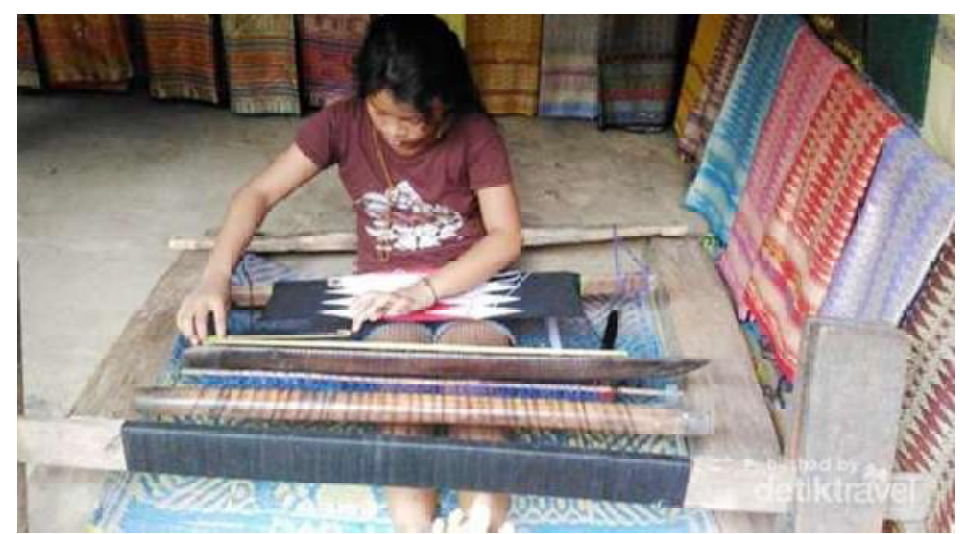

Figure 4 - Weaving culture in Sade Haml

On a micro-scale, there is local cultural wisdom found in the community buildings of Dusun Sade. In a traditional house called Bale Tani, local wisdom uses palm fiber as a roof covering. This material is a climate response given the dry tropical climate to reduce the temperature. Not only concerned with thermal comfort in the interior, but the roof of the house also has a philosophy. The form that rises on the back symbolizes the relationship between humans and God, while the top that piles up in front symbolizes the relationship between humans and others. This philosophy shows that the community attaches importance to the relationship between humans and humans and their God (Gall et al 2011).
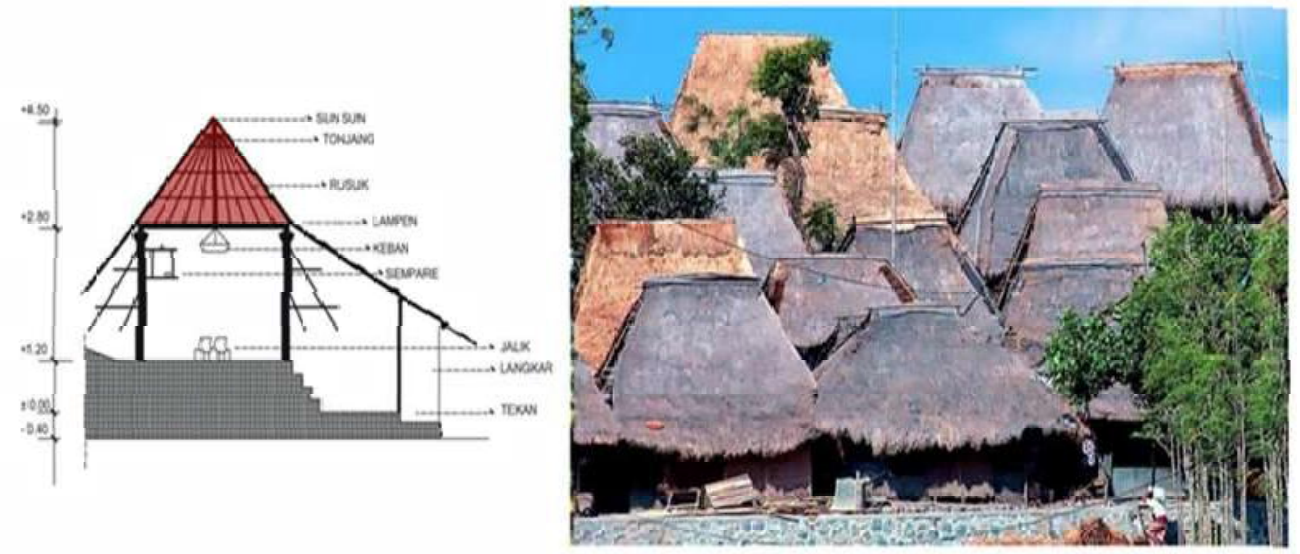

Figure 5 - Roof material using fiber 


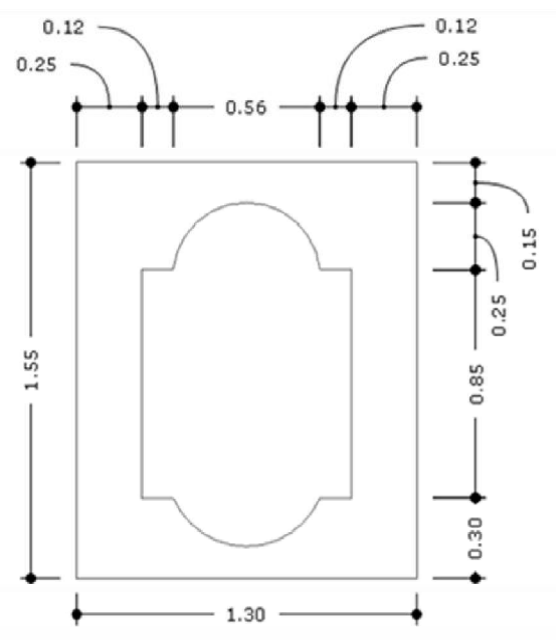

Figure 6 - Door section of Bale Tani

The part of the Bale Tani door has an instilled moral value. Dimensions of the door's height, which has a length of $1.55 \mathrm{~m}$ make guests, will duck. The moral value investing is that everyone who enters the house respects the house owner to keep the door low.

In society, what is very attached to the settlement and community is belief (Mitchell 2013). It is inseparable from the Sasak Native Tribe in Dade Hamlet. Watu Telu and Watu Lima are evidence that community dynamics experience trust. Starting from animismdynamism beliefs, the emergence of Sunan Prapen, the propagator of Islam in the Sasak tribe, made the Sasak community into three groups, namely those who maintained their old beliefs and then fled to the forest (the Boda people) (Quddus 2020). This group was only subject to Sunan Prapen (Watu Telu), a group that conquered and embraced Islam (Watu Lima).

Watu Telu is Islamic teaching which is currently a society's transition from animismdynamism to a community that embraces Islam. The practice persisted because the saints who spread Islam for the first time did not have the opportunity to finish their teachings (Kugle 2011), so that society was trapped during the transition period. Students who leave do not dare change their transition period to complete Islamic practice. That is one reason that is still found in Wetu Telu adherents in modern times. The Watu Telu community only performs three prayers: at Fajr, Maghrib, and Isha. It is believed that three prayers by the Watu Telu community were carried out only by religious teachers and religious leaders. Only three representatives of the daily prayer could be held.

In the Dusun Sade community, an inner room is found in a ladder with three steps. The steps in this internal space are evidence of Islam Watu Telu, which existed at that time.

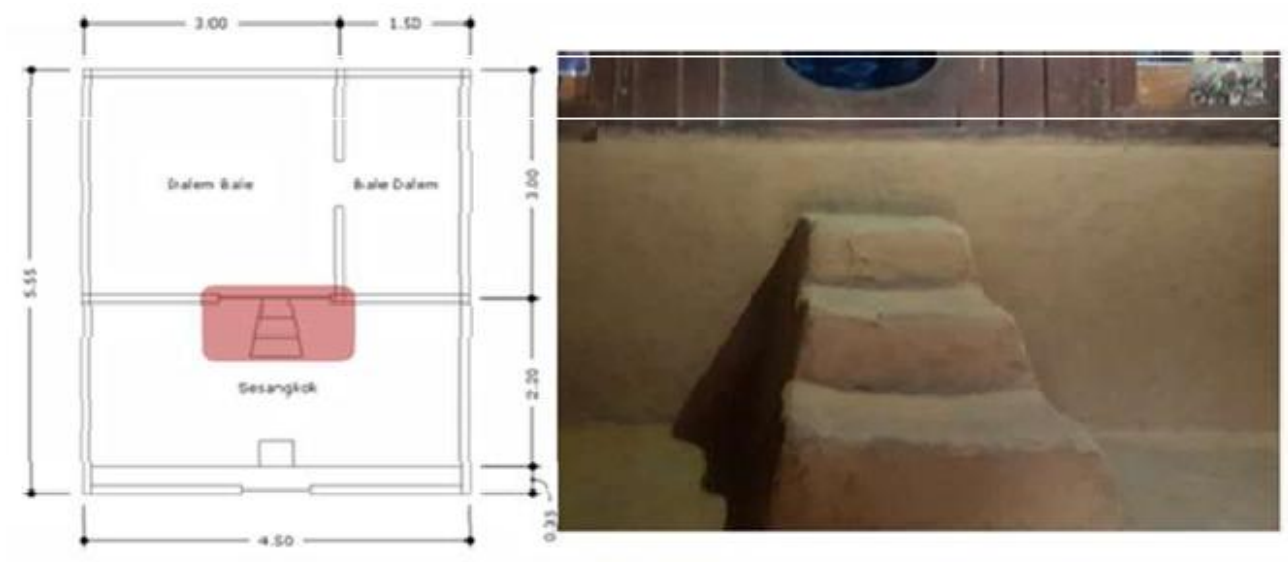

Figure 7 - Watu Telu at Bale Tani 
Watu Lima is true Islam where the people of the Sade Tribe add two steps to their home as a perfect form of Islam that has entered Sade Hamlet.

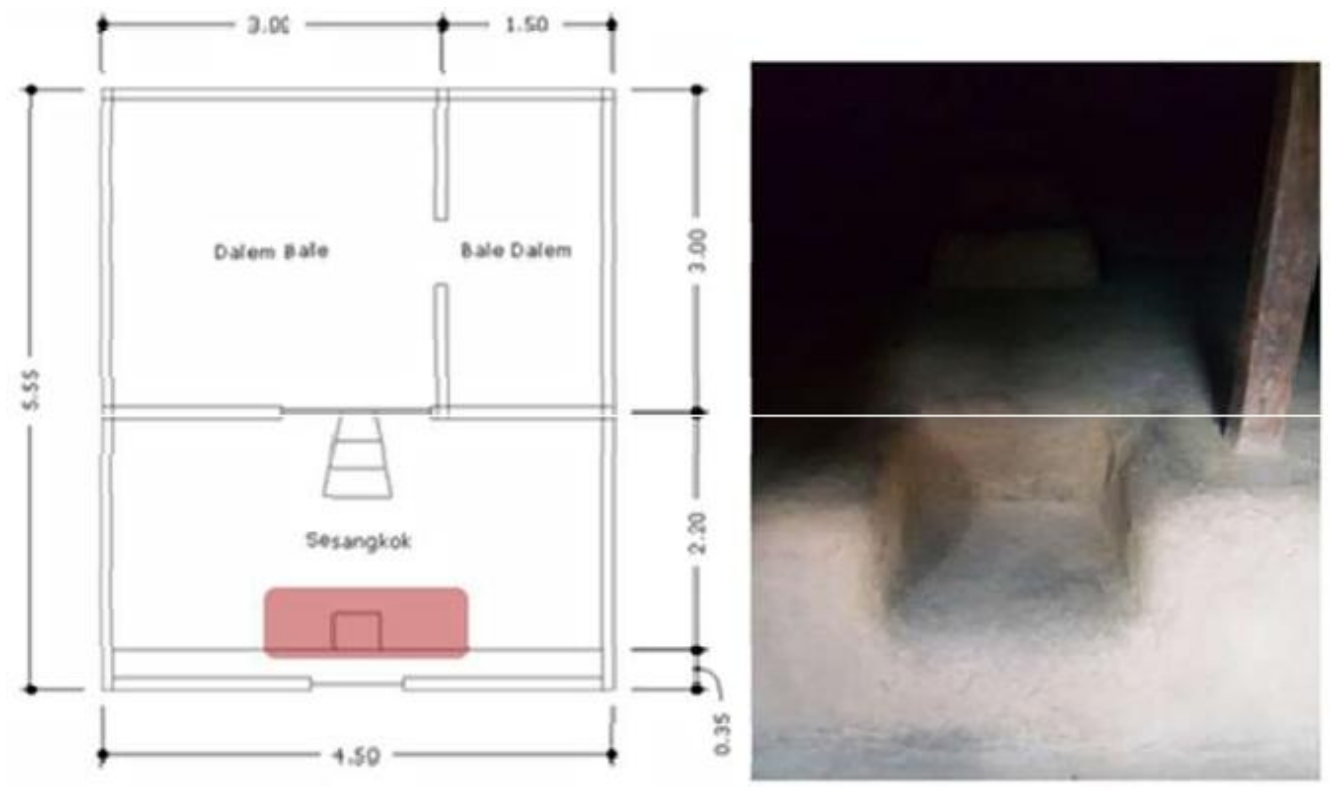

Figure 8 - Watu Lima at Bale Tani house

Sade people cleaning their houses with cow or buffalo dung are married (Rahman et al 2019). They are done to maintain the culture and traditions passed down from generation to generation from their ancestors. And they believe they can repel flies, mosquitoes, and cold houses during the dry season and warms up during the rainy season. Usually, Sade Hamlet residents clean the floors of their homes with cow or buffalo dung once a month to clean the floors of houses from flies or mosques and make their bases strong and not easily cracked.

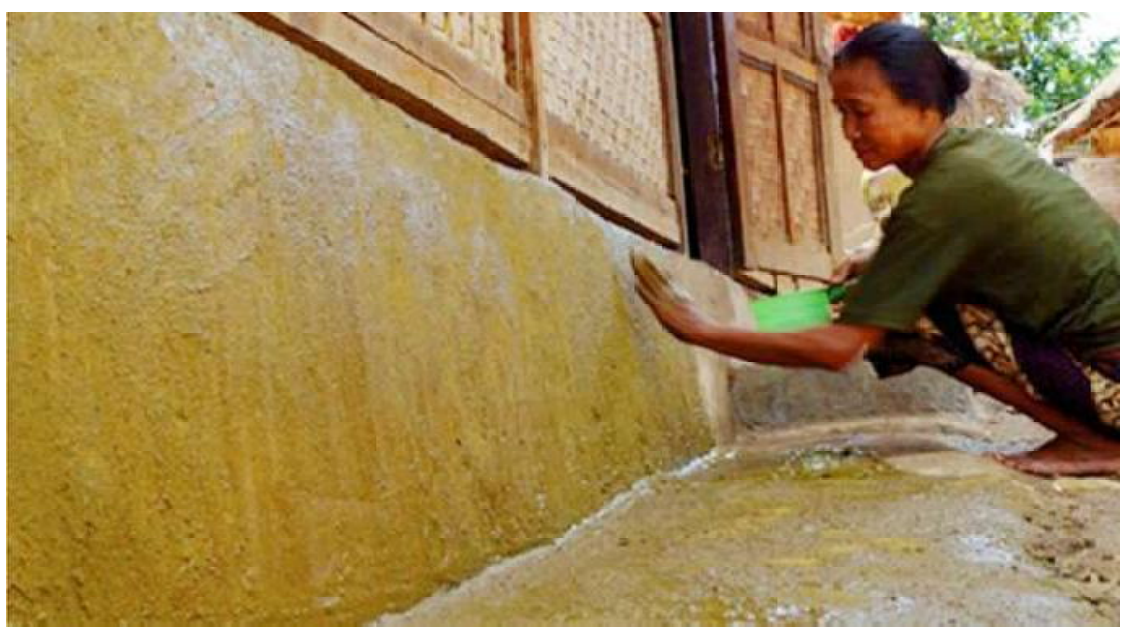

Figure 9 - Mopping with Cow Dung

This house has dimensions of $4.5 \times 5.5$, which one family inhabits. In the traditional indoor building, the function held firmly by the people of the Dusun Sade is similar. In the inner room, there are three rooms, namely Sesangkok, Dalem Bale, and Bale Dalem.

A bowl is a room that works for both the family room and the boy. In this section, there are no partitions to interact without hindrance. Dalem Bale has a function as a bedroom and a kitchen for girls (Anggriani 2020). Bale Dalem has a role as a place of birth.

The first test conducted is the moisture content of the organic waste used. It is necessary to determine the required moisture content. The humidity level test results of cow 
dung can be seen in table 4 , with an average value of $80.5 \%$ humidity content. With this value, animal waste's organic waste will no longer absorb water from outside because it is already saturated. Meanwhile, the moisture content test results for agricultural waste can be seen in table 5 . The moisture content of agricultural waste is $0 \%$ or in arid conditions-these results in colossal water absorption when water is added. Therefore, animal waste with agricultural waste will produce a unique combination.

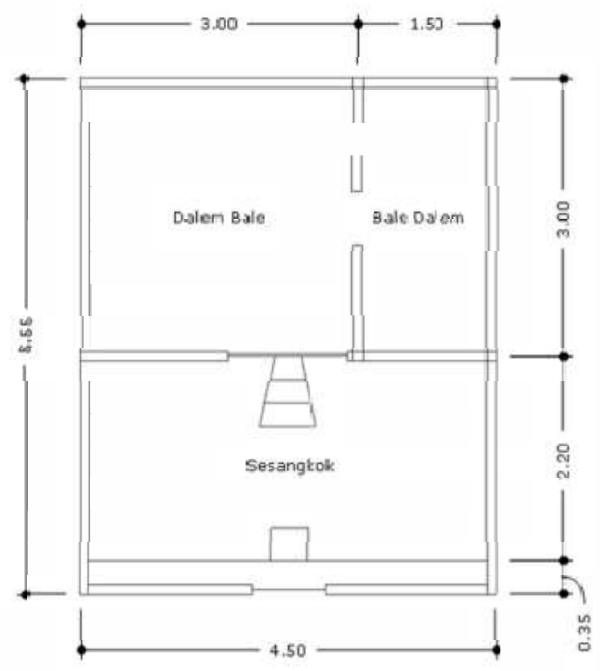

Figure 10 - Plan of Bale Tani

On the one hand, the condition is very saturated with water. On the other hand, it is scorched and absorbs moisture. If mixed, agricultural waste will absorb the water content in animal waste.

Samples using $0.8 \mathrm{~L}$ and $1 \mathrm{~L}$ of water for $1 \mathrm{~kg}$ of animal waste (cow dung) and $250 \mathrm{~kg}$ of agricultural waste (husk ash) are too soft and easily crushed (only by hand kneading). While the sample using $0.4 \mathrm{~L}$ of water, the result is that the sample is too thick or difficult to stir. The optimal water requirement is $0.6 \mathrm{~L}$. The results of the compressive strength of the sample with $0.6 \mathrm{~L}$ of water are as follows:

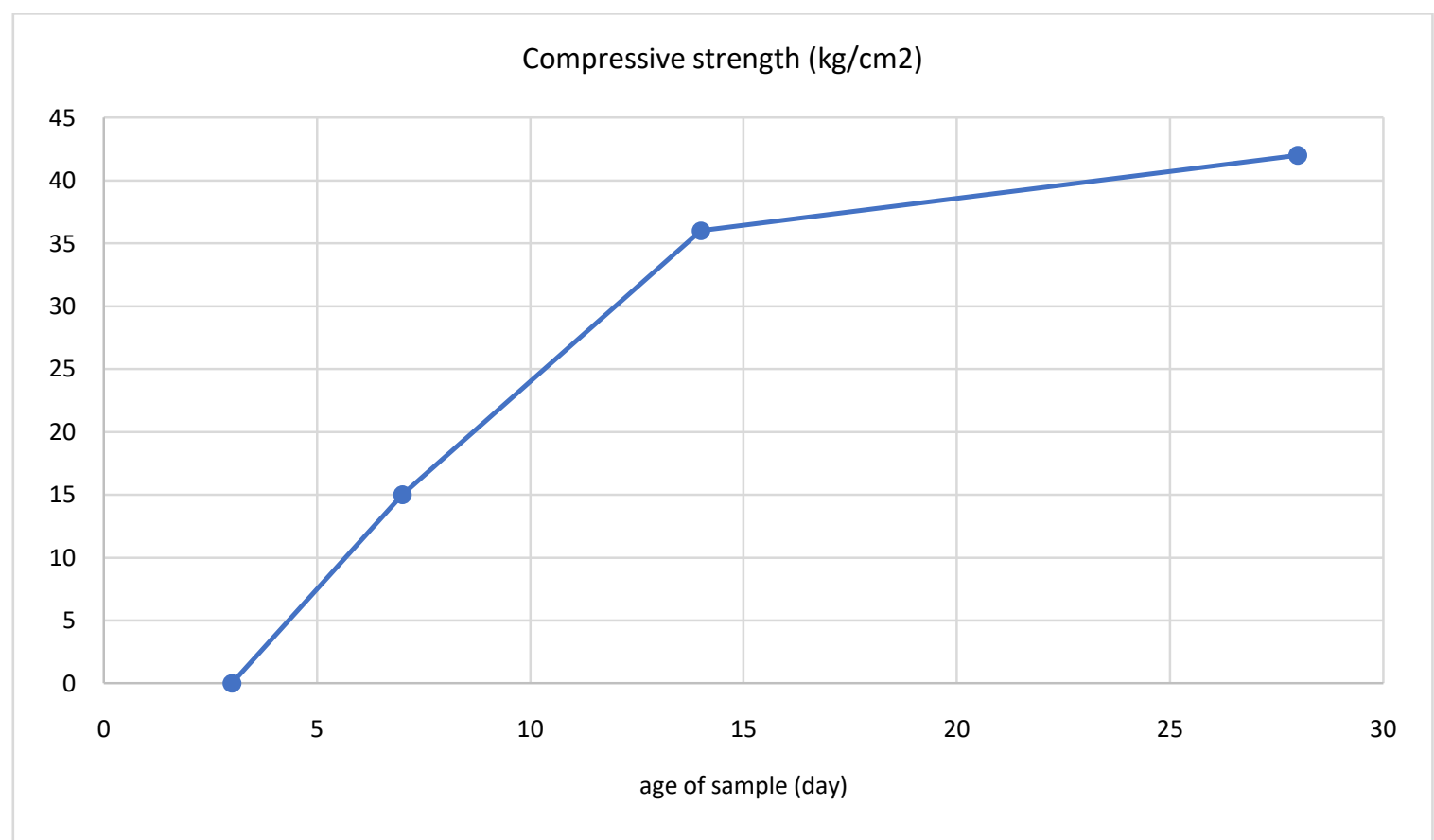

Figure 11 - The average compressive strength of the sample. 
If we look closely, the seven days to 28 days ratio is $15 / 42,35 \%$. Meanwhile, the strength of 14 to 28 days was $36 / 42$, which is $85 \%$. Approximates the graph of increasing the power of standard concrete.

As a comparison, a mortar with a cement and sand composition is 1: 5 . This comparison value is based on the field that the mixture that is often used in the plaster mixture is 1: 5 . The comparison test results can be seen in Table 2.

Table 2 - Compressive strength of mortar organic and PC

\begin{tabular}{llll}
\hline No & Time (days) & Mortar Organic & Mortar PC \\
\hline 1 & 7 & $15 \mathrm{~kg} / \mathrm{cm}^{2}$ & $126.86 \mathrm{~kg} / \mathrm{cm}^{2}$ \\
2 & 14 & $36 \mathrm{~kg} / \mathrm{cm}^{2}$ & $153.73 \mathrm{~kg} / \mathrm{cm}^{2}$ \\
3 & 28 & $42 \mathrm{~kg} / \mathrm{cm}^{2}$ & $220.25 \mathrm{~kg} / \mathrm{cm}^{2}$ \\
\hline
\end{tabular}

From Table 2, it appears that the ratio for seven days of age is $1.2 \%, 2.3 \%$ for 14 days, while the ratio for 28 days is $1.9 \%$. The minimal ratio value indicates that the organic mortar type cannot function as a structural material. The organic type of mortar can only be used for non-structural purposes or architectural ornament. However, the field facts show that this type of mortar is sufficiently able to withstand the weight of wall decorations (photo frames, paintings, etc.) by placing nails. This type of organic mortar is also sufficient to withstand raindrops without experiencing destruction.

The next test was conducted to determine the mortar's specific gravity using animal manure and husk ash. The results of this test can be seen in table 7.

The results above show that the sample volume weight is very light, below the density of water $(1000 \mathrm{Kg} / \mathrm{m} 3)$. It means this sample will float when put into water. This condition is equivalent to a pumice stone's specific gravity, which also has lower specific gravity than water. According to the previous study (Maricar et al 2014), lightweight concrete has a density between $240 \mathrm{~kg} / \mathrm{m}^{3}-900 \mathrm{~kg} / \mathrm{m}^{3}$. Organic mortar is included in the light material category (lightweight) based on this grouping. When combined with its secondary strength characteristics, this organic mortar is classified as a non-structural lightweight material. There are very open opportunities for development in the construction sector, especially in reducing structural loads from these characteristics.

Another test that is carried out is the fire test. The organic mortar specimen is not resistant to fire, indicated by the specimen's crushing to ashes when it is burned.

\section{CONCLUSION}

The settlements formed by the Dusun Sade community have a particular order because traditional values are passed on to their descendants. The order created is not only tangible but also intangible. The maintained charges and the cooperation between communities perpetuate traditional values both physically and socio-culture.

The physical order application from a macro scale does not face north to Mount Rinjani because there is a Dewa Mount Rinjani were facing in that direction is taboo and is considered to be against the gods. Apart from having cosmic beliefs, Sade Hamlet's location was chosen to be a hill to avoid conflicts between other hamlets. Farming as the primary profession makes settlements a linear pattern, making it easy for residents to go to the settlers' farms.

Micro-scale cultural wisdom is manifested by the value of the relationship between humans and humans, humans and their God found on the building's roof. It also instils a matter of respect for the homeowner at the entrance. The existing beliefs are Watu Tetu and Watu Lima, shown in the inner space element in the form of a ladder that leads the dynamics of faith in that period. The use of cow dung as a medium for mopping floors and polishing prevents mosquitoes and flies. The function of the inner space contained in Bale Tani is still maintained until now, indicating that this function can be said to be a sustainable function.

From the characteristic test, conclusions can be drawn:

- For water use, the optimal is $0.6 \mathrm{~L} / \mathrm{Kg}$ because the mixture is not soft and hard; 
- The composition to produce the greatest compressive strength is a combination of water variations of $0.6 \mathrm{~L} / \mathrm{Kg}$, obtained an average compressive strength of 28 days of age, namely $4.3 \mathrm{Kg} / \mathrm{cm}^{2}$;

- Organic mortar has a specific gravity of $990 \mathrm{Kg} / \mathrm{m}^{3}$;

- Organic mortar is a non-structural lightweight material;

- Organic mortar is very susceptible to fire hazards.

Some suggestions that can be given after conducting this research are:

- Need to know the increase in strength until the age of 90 days;

- It needs to be studied about its porosity aspect;

- Need to study resistance to flood hazards (immersion).

\section{FUNDING AND CONFLICTS OF INTEREST}

Financial support from the Directorate of Research and Community Service; Directorate General of Research and Development Strengthening; and Ministry of Research, Technology and Higher Education.

The authors declare no conflicts of interest.

\section{REFERENCES}

1. Ahyar, A., \& Abdullah, S. (2019). Sorong Serah Aji Krama tradition of Lombok Sasak marriage to revive Islamic culture. El Harakah, 21(2), 255.

2. Anggriani, S. D. (2020). The Role of Women in the Layout and Interior of Bale Mengina Traditional House. KnE Social Sciences, 281-290.

3. Dewi, S., \& Putry, I. D. A. (2019). Ethics of Public Service Based Local Wisdom Value. In International Conference on Natural and Social Sciences (ICONSS) Proceeding Series (pp. 324-332).

4. Díaz, S., Demissew, S., Carabias, J., Joly, C., Lonsdale, M., Ash, N., ... \& Zlatanova, D. (2015). The IPBES Conceptual Framework-connecting nature and people. Current opinion in environmental sustainability, 14, 1-16.

5. Erwinsya, E., Handoyo, E., \& Arsal, T. (2020). Merariq Tradition of Sasak Tribe in Social Construction and National Law. Journal of Educational Social Studies, 9(1), 48-55.

6. Gall, T. L., Malette, J., \& Guirguis-Younger, M. (2011). Spirituality and religiousness: A diversity of definitions. Journal of spirituality in Mental Health, 13(3), 158-181.

7. Gilbert, O. (2012). The ecology of urban habitats. Springer Science \& Business Media.

8. Hamzah, A. S., \& Irfan, M. (2018). Local wisdom based tourist village sade lombok organization within the framework of sustainable tourism development. In International Conference on Business Law and Local Wisdom in Tourism (ICBLT 2018) (pp. 129-132). Atlantis Press.

9. Kugle, S. (2011). Sufis and Saints' Bodies: Mysticism, Corporeality, and Sacred Power in Islam. Univ of North Carolina Press.

10. Kusumowidagdo, A., Kaihatu, T. S., Wardhani, D. K., Rahadiyanti, M., \& Swari, I. A. I. (2019). An analysis of sense of place in sade vilagae shopping corridor, Lombok: a study about physical and social factors of cultural shopping area in the Island of Deities. Penerbit Universitas Ciputra.

11. Leonard, S., Parsons, M., Olawsky, K., \& Kofod, F. (2013). The role of culture and traditional knowledge in climate change adaptation: Insights from East Kimberley, Australia. Global Environmental Change, 23(3), 623-632.

12. Maricar, S., Nirmalawati, N., \& Rivani, A. (2014). Pemanfaatan Campuran Mortar Dan Partikel Kayu Sebagai Elemen Inti Balok Beton Komposit. JOURNAL TEKNIK SIPIL DAN INFRASTRUKTUR, 4(2).

13. Mitchell, M. C. (2013). Religion, identity and politics in Northern Ireland: Boundaries of belonging and belief. Ashgate Publishing, Ltd.. 
14. Quddus, A. (2020). Religio-magicism of Sasak: the Qur'anic Mantras in the Healing Rituals of Lombok Community. International Journal of Psychosocial Rehabilitation, 24(2).

15. Rahman, R., Suryawardani, I. G. A. O., \& Wiranatha, A. S. (2019). The Influence of Services' Quality on Intention to Revisit through Mediation of Satisfaction of Visitors at Sasak Sade Village, Central Lombok, West Nusa Tenggara. E-Journal of Tourism, 322-341.

16. Scruton, R. (2013). The aesthetics of architecture. Princeton University Press.

17. Waterson, R. (2012). Living house: an anthropology of architecture in South-East Asia. Tuttle publishing.

18. Widisono, A. (2019). The local wisdom on Sasak Tribe Sade Hamlet Central Lombok Regency. Local Wisdom: Jurnal IImiah Kajian Kearifan Lokal, 11(1), 42-52.

19. Wirawan, I. W. A., \& Widana, I. N. M. (2020). Construction of a multicultural civilization in memarek tradition. International Journal of Innovation, Creativity and Change, 11(4), 126-144. 